\title{
SISTEM VALIDASI KEASLIAN DOKUMEN DIGITAL BERBASIS QR-CODE
}

\author{
Rakhmat Kurniawan. R, Rina Filia Sari, Noor Azizah \\ Fakultas Sains dan Teknologi, Univesitas Islam Negeri Sumatera Utara \\ Jl. IAIN No. 1 Medan, Sumatera Utara \\ rakhmat.kr@uinsu.ac.id, rinafiliasari@uinsu.ac.id, noorazizah@uinsu.ac.id
}

\begin{abstract}
The prolonged Covid-19 pandemic forces each individual to minimize physical contact with other individuals to reduce its spread. The impact created by this restriction is the paralysis of all operational activities from all fields, especially education. All learning activities and academic services cannot be done face to face. To maintain their existence and total paralysis, all institutions have begun to switch their operational systems from offline to online. In tertiary institutions, especially at the State Islamic University of North Sumatra, Medan, learning is transferred using e-learning. However, the academic service system is done manually via chat and email applications. The use of chat and email communication applications in carrying out academic service operations is deemed quite helpful. The obstacle experienced by using these applications is the validation of documents sent by students to the academic or study program. The potential for document forgery using these applications is considered very vulnerable. To minimize document falsification, a system was created that could issue a QR-Code and embedded it into a digital document, where the QR-Code could be verified to determine the validity of the digital document. QR-Code issuance is done using a web-based application using the Codeigniter framework. By using a QR-Code-based validation system, it is hoped that the potential for document forgery can be minimized.
\end{abstract}

Keywords - QR-Code, Authenticity of digital documents, Codeigniter

Abstrak - Pandemi Covid-19 yang berkepanjangan memaksa setiap individu untuk meminimalisir kontak fisik dengan individu lainnya untuk mengurangi penyebarannya. Dampak yang dimunculkan oleh pembatasan ini adalah lumpuhnya seluruh kegiatan operasional dari seluruh bidang, terutama Pendidikan. Seluruh kegiatan pembelajaran dan pelayanan akademik tidak dapat dilakukan dengan bertatap muka. Untuk menjaga eksistensi dan kelumpuhan total, seluruh lembaga mulai beralih sistem operasionalnya dari offline menjadi online. Pada Perguruan Tinggi khususnya di Universitas Islam Negeri Sumatera Utara Medan, pembelajaran dialihkan dengan menggunakan elearning. Namun untuk sistem pelayanan akademis dilakukan secara manual melalui aplikasi chat dan email. Penggunaan aplikasi-aplikasi komunikasi chat dan email dalam melaksanakan operasional pelayanan akademik dirasa cukup membantu. Kendala yang dialami dengan menggunakan aplikasi-aplikasi tersebut adalah validasi keabsahan dokumen yang dikirimkan mahasiswa ke bagian akademik ataupun prodi. Potensi pemalsuan dokumen dengan menggunakan aplikasi-aplikasi tersebut, dirasa sangat rentan. Untuk meminimalisir pemalsuan dokumen, dibuatlah suatu sistem yang dapat menerbitkan QR-Code dan ditanamkan kedalam dokumen digital, dimana QR-Code tersebut dapat di verifikasi untuk mengetahui keabsahan dokumen digital tersebut. Penerbitan QR-Code dilakukan dengan menggunakan aplikasi berbasis web dengan menggunakn framework codeigniter. Dengan menggunakan sistem validasi berbasis QR-Code ini diharapkan potensi-potensi pemalsuan dokumen dapat diminimalisir.

Kata kunci - QR-Code, Keaslian Dokumen Digital, Codeigniter

\section{PENDAHULUAN}

Penyebaran corona virus deseas 2019 (covid-19) yang sangat luas diseluruh dunia sehingga menjadi pandemi global, membuat pemerintah dari setiap negara untuk membatasi aktivitas warganya. Indonesia merupakan salah satu negara yang mengalami penyebaran covid-19 yang sangat luas. Berdasarkan data World Health Organization (WHO) jumlah kasus terkonfirmasi pertanggal 2 november 2020 di Indonesia sebesar 412.784 kasus, dan total kematian sebesar 13.943 jiwa [1].

Untuk menekan angka penyebaran covid-19 dilakukan pembatasan terhadap kegiatan masyarakat. Dampak dari pembatasan ini sangat dirasakan khususnya pada bidang Pendidikan. Hampir seluruh sekolah dan perguruan tinggi dilarang untuk melaksanakan kegiatan belajar mengajar secara tatap muka.

Fakultas Sains dan Teknologi UIN Sumatera Utara Medan, mengalihkan seluruh kegiatan belajar mengajar dari tatap muka menjadi e-learning. Akan tetapi, layanan akademik tidak dapat berjalan baik. Saat ini pelayanan akademik sudah dilakukan daring, namun melalui aplikasi chat dan email.

Penggunaan aplikasi chat dan email tentu saja membutuhkan waktu yang lebih lama dibanding dengan pelayanan secara langsung. Sebagai contoh, petugas layanan akademik akan melayani mahasiswa yang membutuhkan surat bebas praktikum yang akan 
digunakan untuk mendaftar ujian komprehensif. Petugas akan membuat surat tersebut kemudian memindai surat tersebut, dan kemudian mengirimkannya ke mahasiswa.

Cara seperti ini akan menimbulkan potensi pemalsuan dokumen, dimana pada dokumen tersebut telah dibubuhi tanda tangan. Jika mahasiswa telah mendapatkan tanda tangan tersebut, maka mahasiswa dapat mengambil tanda tangan tersebut untuk membuat surat sejenis atas nama mahasiswa lain. Tidak sampai disini, potensi-potensi pemalsuan dokumen lainnya juga akan terbuka.

Untuk meminimalisir potensi pemalsuan dokumen, digunakan QR-Code untuk menggantikan tanda tangan. QR-Code mampu menyimpan data dalam berbagai tipe seperti numerik, alfanumerik, kanji, atau binary. QRCode dapat mengkodekan informasi hingga 7KB [2].

Data yang tersimpan pada QR-Code merupakan identitas dari surat yang diterbitkan yang telah dikodekan menggunakan MD5. Penggunaan algoritma MD5 merupakan standar dalam pembuatan tanda tangan digital atau digital signature. Dengan dilakukan pengkodean terhadap data pada QR-Code, maka potensi untuk membongkar isi data pada QR-Code dapat diminimalisir.

Dari uraian diatas, maka peneliti mengambil judul penelitian " Sistem Validasi Keaslian Dokumen Digital Berbasis QR-Code". Hasil dari penelitian ini diharapkan dapat digunakan pada layanan akademik Fakultas Sains dan Teknologi UIN Sumatera Utara Medan.

\section{A. QR-Code}

Quick Response (QR) Code merupakan sketsa matrix berdimesi 2 yang mengandung data informasi tertentu didalamnya. QR Code berevolusi dari Barcode (kode batang). Barcode tersusun dari susunan garis batang berwarna hitam dan putih yang mengandung data informasi tertentu, ketika di-scan akan mengembalikan data informasi yang bersangkutan [3].

Dalam data pengkodean, Segala bentuk data, baik itu data alphabet, data angka atau numerik, kanji, hiragana, simbol, binary code, dan lain-lain, bisa disimpan kedalam bentuk QR Code. Tampilan QR Code juga lebih kecil jika dibandingkan dengan model barcode. Hal tersebut karena barcode hanya memuat data dalam bentuk horizontal, sedangkan QR Code memuat data dalam bentuk horizontal dan vertikal (matrix). Salah satu keunggulan QR Code yang lain adalah QR Code memiliki toleransi kerusakan sampai dengan 30\%. Sehingga jika sebagian kecil dari QR Code mengalami kerusakan atau cacat, data tetap tersimpan dan dapat terbaca [4].

\section{B. MD5}

Algoritma message digest 5 adalah jenis fungsi hash satu arah. Fungsi hash adalah proses pemberian kode otentikasi terhadap file secara efisien yang mana akan mengubah string input dengan panjang tak terhingga menjadi string output dengan panjang tetap yang disebut nilai hash [5]. MD5 memproses teks masukan ke dalam blok-blok 512 bit, kemudian dibagi menjadi 16 buah sub blok sebesar 32 bit. Keluaran dari algoritma MD5 adalah sebuah set dari 4 buah blok masing-masing 32 bit, yang kemudian menghasilkan nilai hash 128 bit [6]. Langkah-langkah pembuatan message digest pada MD5 adalah sebagai berikut:

1. Padding Bits

2. Penambahan nilai Panjang pesan semula

3. Inisialisasi buffer MD

4. Pengolahan pesan dalam blok berukuran 512 bit

\section{METODE PENELITIAN}

Penelitian ini dilakukan dengan mengumpulkan data yang diperoleh dari lapangan dan penelitianpenelitian yang telah dilakukan sebelumnya.

1. Pengumpulan Data

Pada penelitian ini pengumpulan data dilakukan dengan library research, field research, laboratory reseach, dan interview.

2. Pengolahan Data

Data yang telah dikumpulkan selanjutnya diolah dengan mendefinisikan kebutuhan sistem.

3. Mengembangkan Aplikasi

Setelah menyelesaikan tahap pengolahan data, berikutnya adalah mengembangkan aplikasi dengan membuat rancangan database, input dan interface dari aplikasi.

4. Implementasi

Setelah aplikasi dirancang, maka tahap berikutnya adalah implementasi dengan membuat aplikasi sesuai rancangan yang mampu untuk menghasilkan QR-Code berdasarkan kebutuhan dokumen yang akan diterbitkan serta membaca dan mem-validasi QR-Code dari dokumen yang akan diperiksa. Aplikasi yang akan dibangun berbasis Web, sehingga dapat diakses dari berbagai jenis perangkat.

5. Pengujian

Tahap pengujian adalah tahap dimana sistem yang telah dibangun diuji dengan data yang sesuai dengan sistem sebelumnya. Jika terjadi kesalahan, maka akan dilakukan maintenance dan pengujian ulang hingga tidak ditemukan kesalahan.

\section{HASIL DAN PEMBAHASAN}

Berdasarkan metode penelitian yang telah diuraikan diatas, pada bagian ini akan disajikan pembahasan rancangan dari sistem yang akan dibangun.

\section{A. Rancangan Database}

Pada sistem yang akan dibangun ini, database yang akan dibangun terdiri dari tabel user, tabel mahasiswa, tabel jenis surat, tabel pejabat, tabel qr code dengan struktur seperti pada Gambar 1 dibawah ini. 


\begin{tabular}{|l|}
\multicolumn{1}{|c|}{ tbuser } \\
*idUser \\
Username \\
Password \\
Nama Lengkap \\
NIP \\
\hline
\end{tabular}

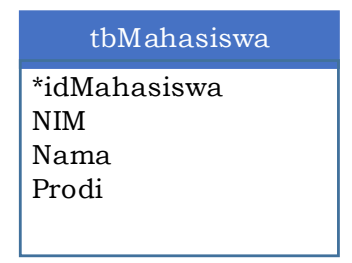

\begin{tabular}{|l|}
\multicolumn{1}{r|}{ tbPejabat } \\
\hline *idPejabat \\
NamaPejabat \\
NIP \\
Jabatan \\
\hline
\end{tabular}

\begin{tabular}{|l|}
\multicolumn{1}{|c|}{ tbjenissurat } \\
\hline idPejabat \\
*idJenisSurat \\
NamaSurat \\
\hline
\end{tabular}

\begin{tabular}{|l|}
\multicolumn{1}{|c|}{ tbQRCode } \\
\hline idJenisSurat \\
idPejabat \\
idMahasiswa \\
*idQRCode \\
MD5Hash \\
NoSurat \\
tglSurat
\end{tabular}

Gambar 1. Struktur Tabel Pada Database

B. Rancangan Input

Rancangan Input pada sistem yang akan dibangun dibagi menjadi 2 (dua) bagian, yaitu:

1. Input untuk menerbitkan QR-Code

Pada bagian ini sistem akan menghasilkan suatu QR-Code yang sesuai dengan kebutuhan dokumen yang akan diterbitkan. User memberikan input yang sesuai dengan tabel QRCode. Input tersebut berupa plaintext yang kamudian akan dilakukan encoding dengan menggunakan MD5. Hasil encoding MD5 selanjutknya akan dikonversi kedalam bentuk citra QR-Code.

2. Input QR-Code yang akan divalidasi

Pada bagian ini sistem user diminta untuk memberikan input berupa dokumen digital dalam format pdf. Selanjutnya sistem akan melakukan ekstraksi QR-Code dari dokumen tersebut. Hasil ekstraksi akan dibaca dan dilakukan decoding terhadap QR-Code. Hasil decoding yang berupa MD5 Hash, akan dicocokkan dengan seluruh record yang ada pada tabel QR-Code untuk mendapatkan identitas dari dokumen tersebut.

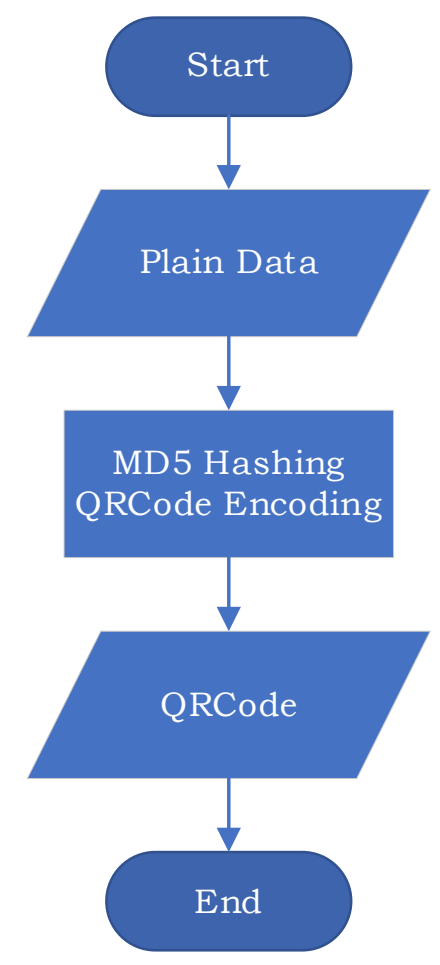

Gambar 2. Flowchart Generate QR-Code

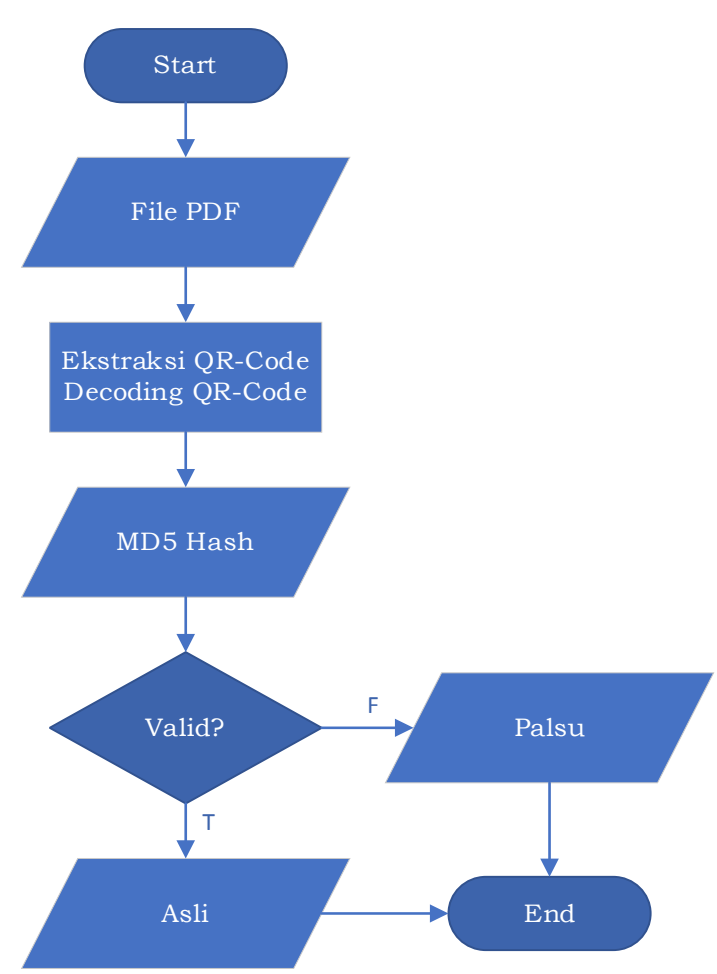

Gambar 3. Flowchart Validasi QR-Code 
C. Rancangan Interface

Rancangan Interface dalam penelitian ini dibagi menjadi 8 (delapan) bagian, yaitu:

1. Interface Login

Pada interface ini digunakan untuk masuk kedalam aplikasi. Gambar 4 dibawah ini merupakan rancangan Interface Login.

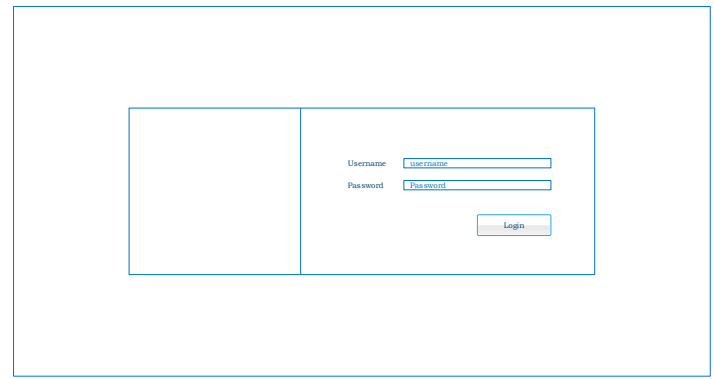

Gambar 4. Interface Login

2. Interface Data User

Pada bagian ini digunakan untuk menampilkan, menambah, ubah, dan hapus data user. Data user merupakan operator yang diberi izin untuk menggunakan aplikasi. Gambar 5 dibawah ini merupakan Interface Data User.

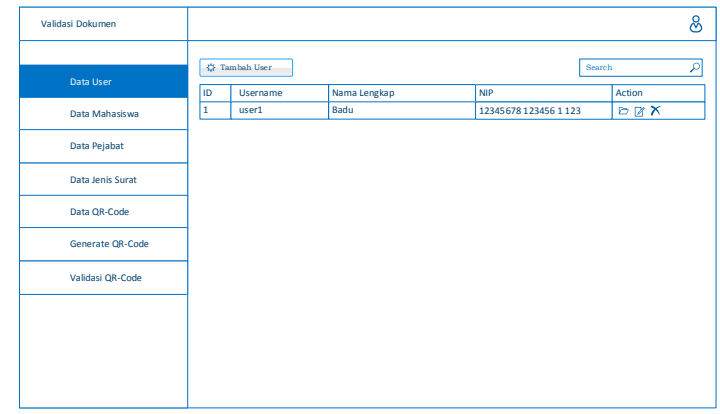

Gambar 5. Interface Data User

3. Interface Data Mahasiswa

Pada interface data mahasiswa digunakan untuk menampilkan data mahasiswa. Terdapat fitur CRUD pada interface tersebut.

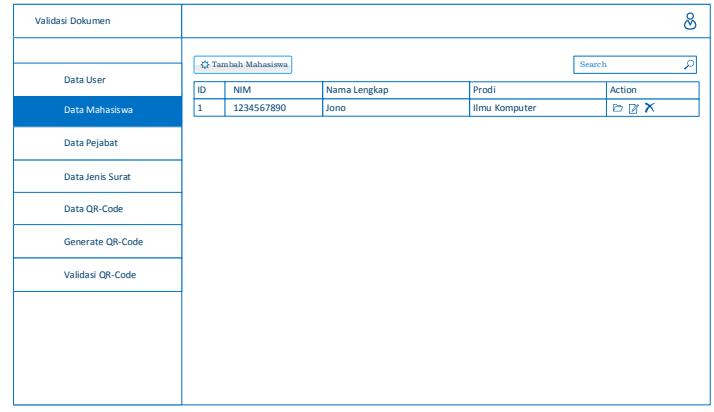

Gambar 6. Interface Data Mahasiswa

4. Interface Data Pejabat

Pada interface data pejabat digunakan untuk menampilkan data pejabat yang berwenang dalam menandatangani surat. Tersedia juga fitur CRUD pada interface ini.

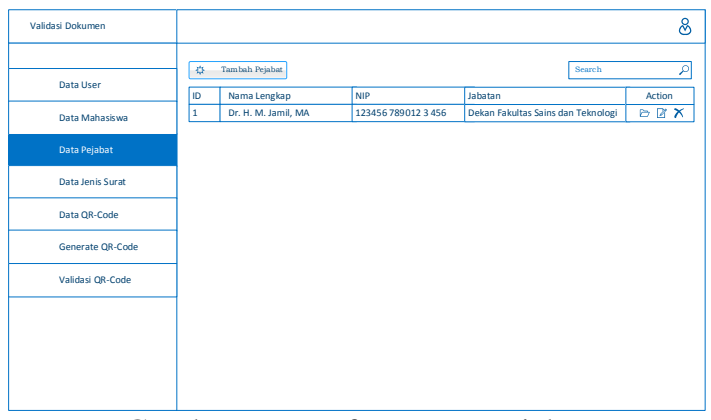

Gambar 7. Interface Data Pejabat

5. Interface Data Jenis Surat

Untuk mengelola Jenis Surat, dapat dilakukan melalui Interface Jenis Surat.

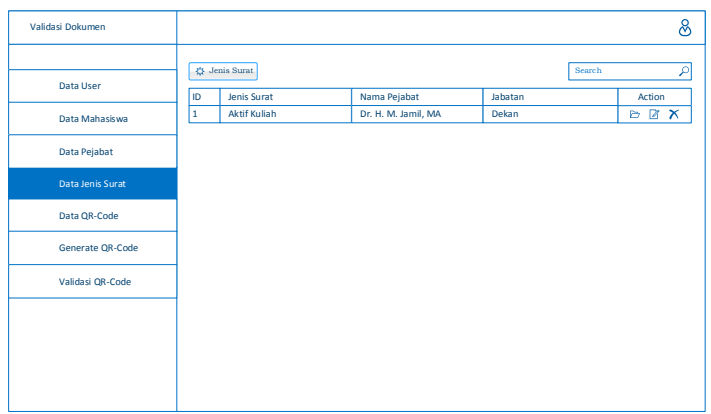

Gambar 8. Interface Jenis Surat

6. Interface Data QR-Code

Pada interface ini digunakan untuk menampilkan data seluruh QR-Code yang telah di generate melalui aplikasi yang akan dibangun.

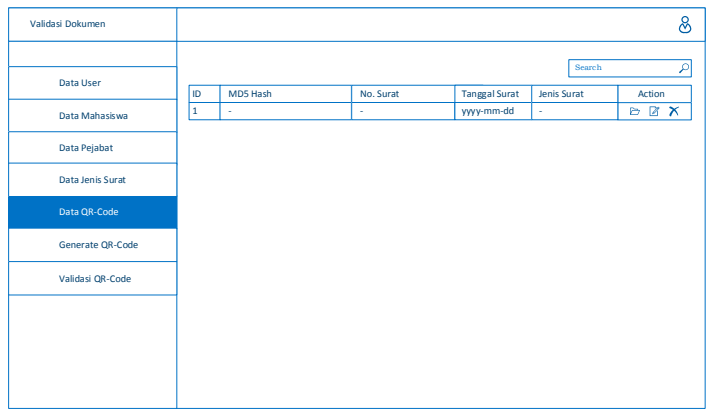

Gambar 9. Interface Data QR-Code

7. Interface Generate QR-Code

Untuk membuat QR-Code yang akan digunakan pada dokumen yang akan diterbitkan dapat dilakukan pada Interface Generate QR-Code. User hanya diminta untuk memberi input No. Surat, NIM dan Jenis Surat yang akan diterbitkan, secara otomatis sistem akan mengeluarkan MD5 Hash dan QR-Code yang akan digunakan. 


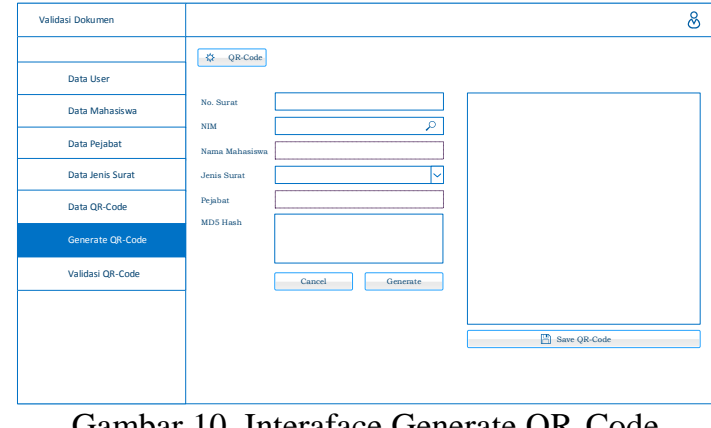

Gambar 10. Interaface Generate QR-Code

8. Interface Validasi QR-Code

Interface Validasi digunakan untuk memvalidasi dokumen yang dibuka pada aplikasi. Setelah dokumen berhasil dibuka, secara otomatis aplikasi akan melakukan ekstraksi QR-Code pada dokumen tersebut. Hasil ekstraksi kemudian akan di encoding untuk dicocokan pada data QR-Code yang terdapat didalam database.

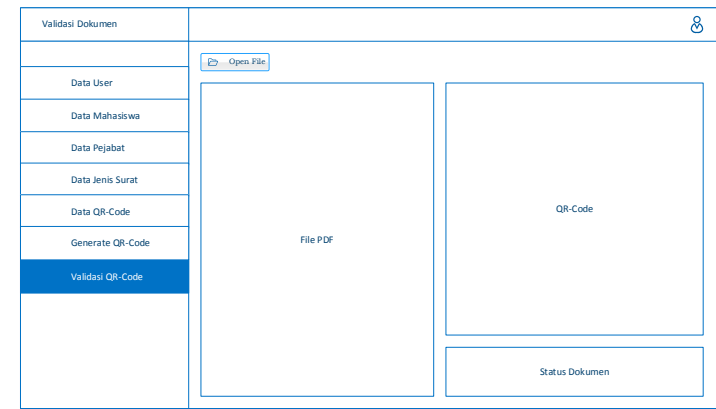

Gambar 11. Interface Validasi QR-Code

D. Tampilan Aplikasi

Tampilan Aplikasi yang akan disajikan merupakan bentuk penerapan dari rancangan yang telah dibuat pada tahapan sebelumnya.

1. Form Login

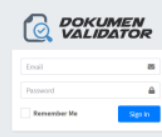

Gambar 12. Form Login

Form login berisi 2 (dua) textbox yang digunakan sebagai autentikasi user. Username yang digunakan sebagai autentikasi berupa email dan password berupa free text.

2. Form Data User

Form Data User menyajikan tombol untuk menambah data user dan search box untuk mencari user. Pada tabel yang tampil pada form tersebut digunakan untuk menampilkan seluruh user yang telah terdaftar. Pada setiap record tersedia tombol aksi untuk melihat detail user, edit, dan hapus user.

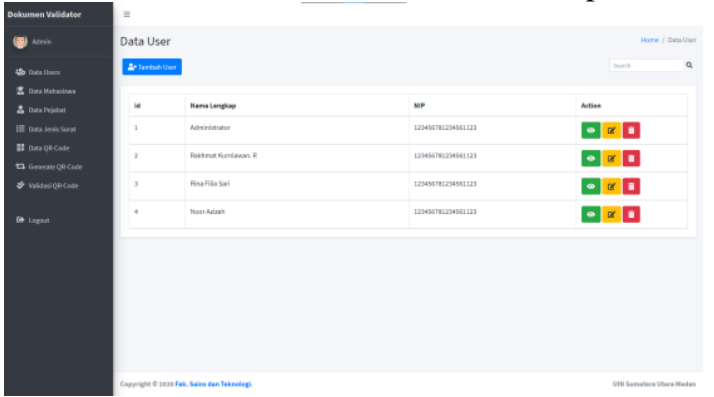

Gambar 13. Form Data User

3. Form Data Mahasiswa

Berisi seluruh data mahasiswa yang telah masuk kedalam database aplikasi. Fitur yang tersedia pada form data mahasiswa adalah sama dengan fitur pada form data user.
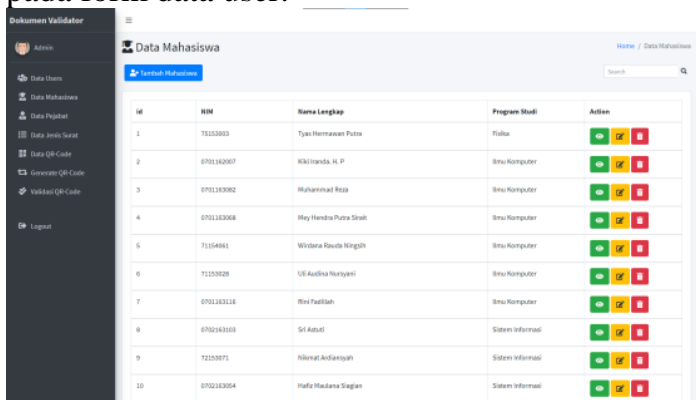

Gambar 14. Form Data Mahasiswa

4. Form Data Pejabat

Menyajikan seluruh data pejabat yang berwenang dalam menerbitkan dokumen. Fitur yang tersedia pada form ini juga sama pada form sebelumnya.
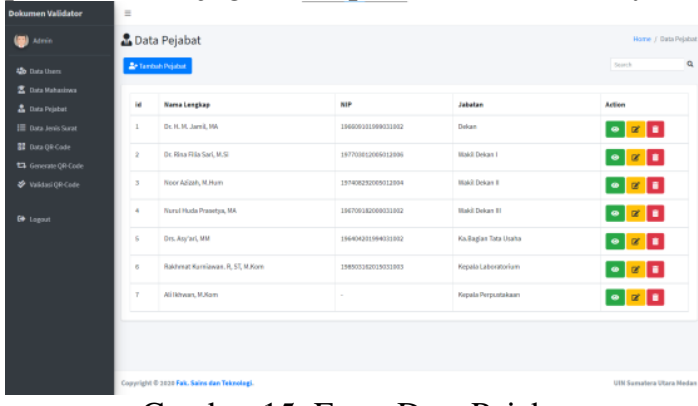

Gambar 15. Form Data Pejabat

5. Form Data Jenis Surat

Form ini menyajikan jenis-jenis surat yang diterbitkan beserta pejabat yang menandatanganinya. Fitur pada form ini juga sama seperti fitur pada form sebelumnya. 


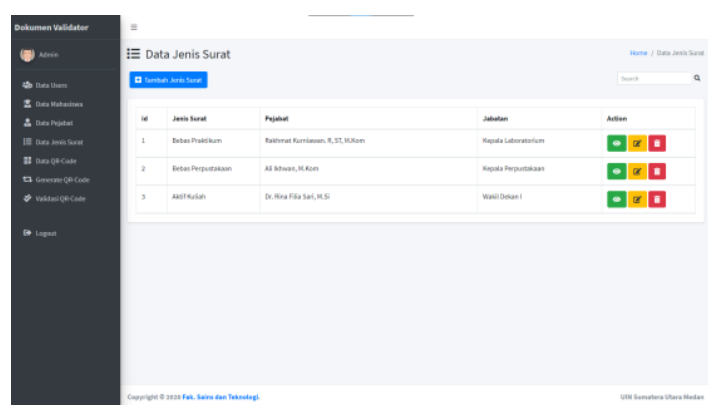

Gambar 16. Form Data Jenis Surat

6. Form Data QR-Code

Pada form ini akan menyajikan seluruh surat dan QR-Code yang telah diterbitkan.

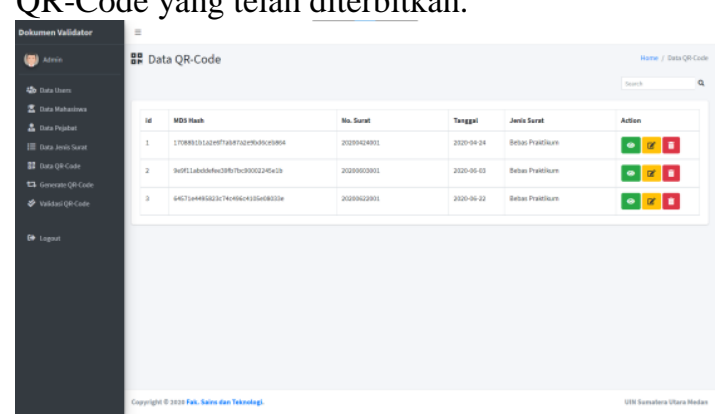

Gambar 17. Form Data QR-Code

7. Form Generate QR-Code

Untuk menerbitkan dokumen digital baru beserta QR-Code dapat menggunakan form ini. User diminta untuk memasukkan data sesuai field yang telah disediakan pada form.

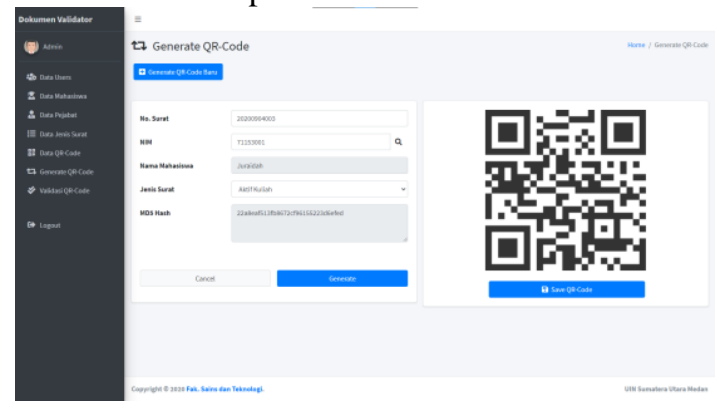

Gambar 18. Form Generate QR-Code

8. Form Validasi QR-Code

Untuk melakukan validasi terhadap suatu dokumen, dapat menggunakan form validasi ini. User diminta untuk melakukan upload terhadap dokumen tersebut, kemudian aplikasi akan melakukan ekstraksi QR-Code pada dokumen tersebut. Hasil ekstraksi akan di-encoding untuk mencari identitas dari dokumen tersebut pada database.

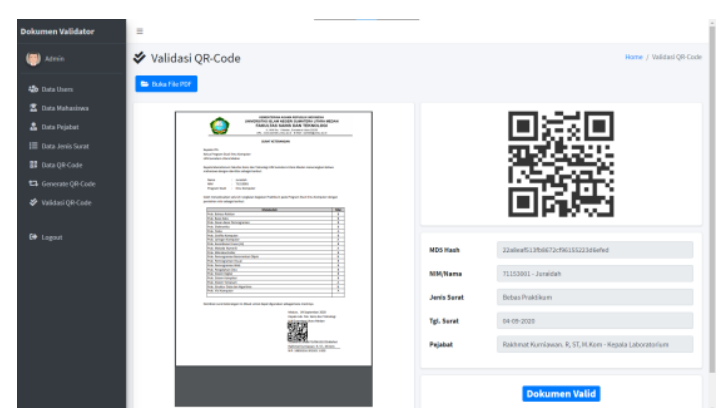

Gambar 19. Form Validasi QR-Code

E. Pengujian

Tabel 1. Pengujian Black Box

\begin{tabular}{|c|c|c|c|}
\hline No. & $\begin{array}{c}\text { Nama } \\
\text { Pengujian }\end{array}$ & Hasil & Kesimpulan \\
\hline 1 & $\begin{array}{l}\text { Manajemen } \\
\text { Data User }\end{array}$ & $\begin{array}{l}\text { Admin dapat } \\
\text { melakukan CRUD } \\
\text { (Create-Read- } \\
\text { Update-Delete) } \\
\text { pada data user }\end{array}$ & Valid \\
\hline 2 & $\begin{array}{l}\text { Manajemen } \\
\text { Data } \\
\text { Mahasiswa }\end{array}$ & $\begin{array}{lr}\text { User } & \text { dapat } \\
\text { melakukan CRUD } \\
\text { (Create-Read- } \\
\text { Update-Delete) } \\
\text { pada } \\
\text { mahasiswa data } \\
\end{array}$ & Valid \\
\hline 3 & $\begin{array}{l}\text { Manajemen } \\
\text { Data } \\
\text { Pejabat }\end{array}$ & $\begin{array}{l}\text { User dapat } \\
\text { melakukan CRUD } \\
\text { (Create-Read- } \\
\text { Update-Delete) } \\
\text { pada data pejabat }\end{array}$ & Valid \\
\hline 4 & $\begin{array}{l}\text { Manajemen } \\
\text { Data Jenis } \\
\text { Surat }\end{array}$ & $\begin{array}{l}\text { User dapat } \\
\text { melakukan CRUD } \\
\text { (Create-Read- } \\
\text { Update-Delete) } \\
\text { pada data Jenis } \\
\text { Surat }\end{array}$ & Valid \\
\hline 5 & $\begin{array}{l}\text { Manajemen } \\
\text { Data QR- } \\
\text { Code }\end{array}$ & $\begin{array}{ll}\text { User } & \text { dapat } \\
\text { melakukan } & \text { RUD } \\
\text { (Read-Update- } \\
\text { Delete) pada } \\
\text { Code }\end{array}$ & Valid \\
\hline 6 & $\begin{array}{l}\text { Penerbitan } \\
\text { Dokumen }\end{array}$ & $\begin{array}{lr}\text { User } & \text { dapat } \\
\text { menerbitkan } & \\
\text { dokumen } & \text { baru } \\
\text { beserta } & \text { QR-Code } \\
\text { sebagai } & \text { digital } \\
\text { signature. } & \end{array}$ & Valid \\
\hline 7 & $\begin{array}{l}\text { Validasi } \\
\text { Dokumen }\end{array}$ & $\begin{array}{l}\text { User dapat } \\
\text { melakukan upload } \\
\text { dokumen, ekstraksi, } \\
\text { decoding QR-Code, } \\
\text { dan pencarian } \\
\text { identitas dokumen } \\
\text { didalam databas. }\end{array}$ & Valid \\
\hline
\end{tabular}




\section{KESIMPULAN}

Berdasarkan penelitian ini, maka dapat diambil kesimpulan sebagai berikut:

1. QR-Code dapat digunakan sebagai digital signature untuk validasi keaslian dokumen digital.

2. Aplikasi Validasi Dokumen ini dapat digunakan untuk menerbitkan dokumen digital dan melakukan validasi terhadap dokumen digital.

3. Aplikasi validasi dokumen ini dapat digunakan untuk meminimalisir potensi pemalsuan terhadap dokumen digital dalam pelayanan akademik di Fakultas Sains dan Teknologi UIN Sumatera Utara Medan.

\section{DAFTAR PUSTAKA}

[1] World Health Organization, "Indonesia: Coronavirus Disease (COVID-19) Dashboard," 2020. .

[2] Y. Widiantoro, "Implementasi qrcode pada berkas kelulusan mahasiswa berbasis pdf web," Semin. Nas. Ilmu Komput. (SNIK 2015), 2015.

[3] A. Wijaya and A. Gunawan, "Penggunaan Qr Code Sarana Penyampaian Promosi Dan Informasi Kebun Binatang Berbasis Android," Bianglala Inform., 2016.

[4] Sunarto, "Perancangan Sistem Manajemen Atk pada BAAK UIB Berbasis Android," Universitas Internasional Batam, 2020.

[5] R. Munir, "Kriptografi," in 2, 2019.

[6] N. Hayati, "Implementasi Algoritma RC4A dan MD5 untuk Menjamin Confidentiality dan Integrity pada File Teks," J. Penelit. Tek. Inform., 2017. 